\title{
Peningkatan Perilaku Sosial Anak melalui Permainan Tradisional Sumatera Barat
}

\author{
Cici Ratna Sari ${ }^{\bowtie}$, Sofia Hartati ${ }^{2}$, Elindra Yetti $^{3}$ \\ Pendidikan Anak Usia Dini, Universitas Negeri Jakarta
}

\begin{abstract}
Abstrak
Penelitian ini bertujuan untuk mendeskripsikan proses dan hasil belajar melalui permainan tradisional Sumatera Barat dalam meningkatkan perilaku sosial. Penelitian ini dilakukan di TK Aster Indah Korong Balai Satu, Provinsi Sumatera Barat pada bulan April 2019. Subjek penelitian adalah kelompok A sebanyak 10 siswa. Penelitian ini menggunakan metode penelitian tindakan. Prosedur penelitian terdiri dari: perencanaan, tindakan dan observasi, refleksi. Dilakukan untuk 12 pertemuan dibagi menjadi dua siklus. Teknik pengumpulan data dilakukan melalui observasi, wawancara, dokumentasi dan catatan lapangan. Teknik analisis data yang digunakan dalam penelitian ini adalah analisis data kualitatif dan kuantitatif. Hasil yang diperoleh dari evaluasi siswa pada setiap siklusnya adalah sebagi berikut: siklus I $65,02 \%$ dari siswa yang sudah mencapai skor 75 , sedangkan pada siklus II terjadi peningkatan menjadi $84,25 \%$ dari siswa yang sudah mencapai skor 75 . Simpulan penelitian ini bahwa permainan tradisional Sumatera Barat efektif digunakan sebagai pembelajaran untuk meningkatkan perilaku sosial anak di TK Aster Indah Korong Balai Satu Provinsi Sumatera Barat.
\end{abstract}

Kata Kunci: perilaku sosial; permainan tradisional sumatera barat; penelitian tindakan

\begin{abstract}
This study aims to describe the process and learning outcomes through traditional West Sumatra games in improving social behavior. This research was conducted at Aster Indah Korong Kindergarten, Balai Satu, West Sumatra Province in April 2019. The research subjects were group A as many as 10 students. This study uses action research methods. The research procedure consists of: planning, action and observation, reflection. The 12 meetings were divided into two cycles. Data collection techniques are carried out through observation, interviews, documentation and field notes. The data analysis technique used in this study is the analysis of qualitative and quantitative data. The results obtained from student evaluations in each cycle are as follows: cycle I $65.02 \%$ of students who have achieved a score of 75 , while in the second cycle there is an increase to $84.25 \%$ of students who have achieved a score of 75. The conclusion of this study is that West Sumatra traditional games are effectively used as learning to improve children's social behavior at the Aster Indah Korong Kindergarten, Balai Satu, West Sumatra Province.
\end{abstract}

Keywords: social behavior; traditional west sumatra games; action research

Copyright (c) 2019 Cici Ratna Sari, Sofia Hartati, Elindra Yetti

$\triangle$ Corresponding author :

Address : Jakarta Timur, Indonesia

ISSN 2356-1327 (Media Cetak)

Email : ciciratnasari45@gmail.com

ISSN 2549-8959 (Media Online) 


\section{PENDAHULUAN}

Salah satu aspek penting yang harus dikembangkan pada usia dini untuk menunjang keberhasilan individu dalam hidup maka sejak kecil anak perlu mempelajari kemampuan tertentu, khususnya kemampuan sosial. Seperti penelitian yang dilakukan oleh Yusuke Takahashi, Kensuke Okada, et, al yang membahas tentang kemampuan sosial: Beberapa proyek besar jangka panjang pada sekolah umum usia dini telah mengindentifikasi karakteristik perkembangan kemampuan sosial anak, kemampuan sosial anak dipahami dan dirasakan oleh orang tua, kemudian akan berkembang saat anak di usia TK hingga kelas 3 SD (Takahashi, Okada, Hoshino, \& Anme, 2015). Beberapa proyek besar jangka panjang pada sekolah umum usia dini telah mengindentifikasi karakteristik perkembangan kemampuan sosial anak, kemampuan sosial anak dipahami dan dirasakan oleh orang tua, kemudian akan berkembang saat anak di usia TK hingga kelas 3 SD. Berdasarkan hasil penelitian tersebut dapat disimpulkan bahwa melalui berbagai pengalaman anak berinteraksi sosial dengan anak lain maupun orang dewasa disekitarnya diharapkan mampu mencapai kematangan dalam kemampuan sosial. Seperti penelitian yang dilakukan oleh Hazar Mafra menunjukkan fakta bahwa anak-anak dengan kesulitan belajar perlu mengembangkan keterampilan belajar dan keterampilan sosial melalui program intervensi pendidikan (Mafra, 2015). Berdasarkan hasil penelitian tersebut menggambarkan bahwa stimulus lingkungan membawa pengaruh pada perkembangan perilaku sosial seseorang.

Hal ini sejalan dengan penelitian Serpil Pekdoğan dalam penelitiannya Investigation of the Effect of Story-Based Social Skills Training Program on the Social Skill Development of 56 Year-old Children bahwa investigasi efek program pelatihan keterampilan berbasis cerita dalam mengembangkan keterampilan sosial anak usia 5-6 tahun. (Pekdoğan, 2016) Jika anak berada di lingkaran sosial yang benar maka perilaku sosial anak akan terlihat lebih baik dibandingkan dengan anak yang salah dalam lingkaran sosialnya. Perilaku sosial erat kaitannya dengan perilaku bersosialisasi atau social interaction skill, perilaku ini merupakan fondasi bagi perkembangan perilaku anak berintekrasi dengan lingkungan secara lebih luas. Dalam berintekrasi dengan orang lain, anak tidak hanya dituntut untuk mampu berintekrasi secara baik dengan orang lain, tetapi terkait juga didalamnya bagaimana ia mampu mengendalikan dirinya secara baik. Apabila pengalaman yang dialami anak adalah pengalaman yang positif, maka akan berpengaruh baik juga pada aspek perkembangan. Begitu juga sebaliknya, jika pengalaman yang dialami adalah negatif, maka akan berdampak buruk pada anak terutama pada kesehatan mental, sosial emosional dan perilaku sosialnya.

Kemampuan Perilaku sosial sangat dibutuhkan oleh anak usia dini karena ketika anak memiliki perilaku sosial yang baik, anak akan mudah beradaptasi dengan lingkungan baru. Omeroglu, menyatakan Seorang anak dibesarkan untuk menunjukkan perilaku seperti yang diharapkan oleh masyarakat tergantung pada perkembangan sosial. Pada perkembangan sosial anak, tahun awal merupakan dasar sosial masa depan mereka untuk berperilaku sosial(Omeroglu, 2015). Sejalan dengan penelitian yang dilakukan oleh Yanrisca Sany tentang "Perilaku Sosial Pada Anak Usia Dini yang Mendapatkan Pembelajaran Bilingual"(Rachmana, 2013). Hasilnya menunjukkan bahwa perilaku sosial yang terbentuk adalah mengalah, tidak mengejek dan menggertak, tidak pernah bertengkar, mau berbagi makanan dan minuman, bisa mematuhi aturan, bisa membaur dengan yang lain, memberi dukungan, ramah, mandiri, mau bekerjasama, mau membantu, mudah beradaptasi, berperilaku atas inisiatif sendiri dan berperilaku baik yang mejadi ciri khas dari masing masing subjek.

Perilaku sosial pada anak usia dini ini diarahkan untuk pengembangan sosial yang baik, seperti menolong, membantu, berbagi, dan menyumbang atau menderma (Susanto, 2011). Ini sejalan dengan penelitian Fajar Luqman Tri A. meneliti tentang Perilaku Sosial Anak Usia Dini Di Lingkungan Lokalisasi Guyangan hasil penelitian menunjukan bentuk 
perilaku sosial positif yang berkembang diantara kedua subjek penelitian yaitu kerjasama, kemurahan hati, kepedulian dan mudah beradaptasi dengan orang baru. Selain itu ada juga perilaku sosial negatif yaitu perilaku penguasa, ketergantungan akan kasih sayang perhatian orang lain dan antagonisme (Tri, 2016). Jadi dapat disimpulkan perilaku sosial pada anak usia dini ini diarahkan untuk pengembangan sosial yang baik, seperti kerja sama, tolong-menolong, berbagi simpati, kemurahan hati, empati dan saling membutuhkan satu sama lain.

Hal ini sejalan dengan penelitian Findlay "Links between empathy, social behavior, and social understanding in early childhood" Hubungan antara empati, perilaku sosial, dan pemahaman sosial pada anak usia dini yang hasilnya menunjukkan bahwa anak-anak yang lebih empatik dilaporkan menunjukkan perilaku prososial yang lebih besar dan lebih sedikit agresi dan penarikan sosial. Di Selain itu, anak-anak yang berempati menunjukkan pemahaman yang lebih matang tentang rasa malu dan agresi dibandingkan dengan yang kurang berempati teman sebaya (Findlay, Girardi, \& Coplan, 2006). Hal ini menunjukkan bahwa anak-anak yang empatik lebih sensitif secara sosial, baik dari segi pemahaman sosial mereka terhadap orang lain serta perilaku sosial mereka sendiri.

Ada beberapa orang tua yang mengkhawatirkan perilaku sosial anaknya. Seperti penelitian yang dilakukan oleh Fiona K. Mensah mengenai Early Puberty and Childhood Social and Behavioral Adjustment mengenai laporan orang tua yang lengkap, Orang tua melaporkan kesulitan perilaku dan penyesuaian psikososial yang terjadi pada anak rentang usia 4-5 hingga 10-11 tahun (Mensah et al., 2013). Berdasarkan hasil penelitian tersebut, menggambarkan kekhawatiran orang tua terhadap perilaku sosial anak dan sangat berharap sekolah dapat memberikan stimulasi pengembangannya. Namun sayangnya, menurut Claproth perilaku sosial sering kali dilupakan dalam pendidikan padahal wilayah yang terlupakan ini sesungguhnya penting di masyarakat (Richard Claproth, 2012). Sama halnya di TK, perilaku sosial anak kurang dipandang oleh pendidik karena pendidik lebih fokus kepada bagian akademik saja. Anak-anak dengan perilaku sosial yang rendah akan menarik diri dari lingkungan sekitarnya dan akan berdampak pada penurunan hubungan perilaku sosial dimasa perkembangan berikutnya.

Hurlock menyatakan bahwa beberapa pola perilaku sosial yang berkembang pada masa kanak-kanak yaitu: (1) meniru/imitasi; (2) persaingan; (3) kerja sama; (4) simpati; (5) empati; (6) dukungan sosial; (7) mau berbagi. Selain itu beberapa pola perilaku anti sosial anak misalnya: (1) negativisme atau melawan otoritas orang dewasa, (2) agresif yakni berlaku kasar baik fisik maupun bahasa verbal melalui makian atau kata-kata kasar, (3) perilaku berkuasa, (4) memikirkan diri sendiri, (5) mementingkan diri sendiri, (6) merusak, (7) pertentangan sex (Hurlock, 1980).

Dengan demikian, peran guru dan orangtua sangatlah penting dalam mendidik anak menjadi pribadi yang sosial, perilaku sosial yang rendah tersebut dapat ditingkatkan dengan bermain. Sesuai dengan prinsip pembelajaran bahwa untuk menstimulasi semua potensi anak yaitu belajar melalui bermain. Seperti penelitian yang dilakukan Guida Veiga dalam penelitiannya" Preschoolers' free play -connections with emotional and social functioning" Bermain bebas anak usia dini berhubungan dengan emosional dan fungsi sosial (Veiga, Neto, \& Rieffe, 2016). Hasil penelitian menunjukkan bahwa permainan bebas membantu mencegah perkembangan perilaku eksternalisasi yang mengganggu.

Menurut Eagleton bahwa integrasi seni budaya sebagai sumber pengetahuan anak memahami, menganalisa dalam menerapkan pengetahuan, baik bahan, bentuk bahasa serta konsep kreativitas karya seni (Solberg, 2016). Bermain seni budaya yang menyenangkan dapat membentuk proses tumbuh kembang yang maksimal. Seperti penelitian Ren mengenai "Social competence, cultural orientations and gender differences: a study of Mandarin-English bilingual preschoolers" bahwa terdapat hubungan perilaku sosial yang diberikan berdasarkan turun-temurun (Ren \& 
Wyver, 2016). Kultur yang diberikan setiap tempat itu berbeda maka berdampak kepada perilaku sosial seseorang. Seperti penelitian Khasanah, et,.al. peneltian tentang permainan tradisional sebagai media stimulasi aspek perkembangan anak usia dini yang hasilnya menunjukkan bahwa permainan tradisional tersebut merupakan sarana dalam mengembangkan aspek perkembangan dasar anak (fisik-motorik, kognitif, sosial-emosional dan bahasa (Khasanah, Prasetyo, \& Rakhmawati, 2011). Berdasarkan hasil penelitian menggambarkan bahwa kultur permainan tradisional mempunyai banyak manfaat bagi perkembangan aspek anak.

Hapidin dan Yenina meneliti juga tentang pengembangan model permainan tradisional dalam membangun karakter anak usia dini yang hasilnya menunjukkan bahwa melalui permainan tradisional edukatif akan membantu anak mengembangkan berbagai aspek perkembangan secara holistik dan terintegrasi serta terbangunnya karakter positif (Hapidin, 2016). Berdasarkan hasil penelitian di atas jelas bahwa permainan tradisional menstimulasi seluruh aspek bahkan termasuk karakter dan perilaku sosial anak. Gelisli, Yazici juga meneliti yang hasil menunjukkan terlihat bahwa permainan tradisional memiliki fitur meningkatkan motorik anak, perkembangan sosial dan emosional, kognitif dan bahasa. Berdasarkan hasil penelitian menggambarkan bahwa permainan tradisional benar-benar mengajarkan anak-anak untuk menjadi kreatif dalam membuat aturan permainan, kreatif dalam belajar, membuat perjanjian, mematuhi aturan-aturan yang telah dibuat dan belajar untuk menjadi jujur kepada diri mereka sendiri dan orang lain. Permainan tradisional memiliki kekuatan untuk merangsang perkembangan anak usia dini.

Menurut Karachle bahwa gaya belajar bermain melalui bermain drama, musik dan permainan bentuk tim sebagai kekayaan budaya mendorong mengekspresikan diri, menyadari kemampuannya (Karachle, Dania, \& Venetsanou, 2012). Perkembangan perilaku melalui pembelajaran bersama dengan permainan dapat membantu perkembangan pada aspek kognitif, afektif, psikomotor yang berkaitan dengan interaksi kerjasama sosial anak pada sesama temannya juga cinta lingkungan.

Berdasarkan beberapa hasil penelitian pada paragraf diatas dapat diketahui bahwa permainan tradisional dapat memberikan manfaat terhadap perkembangan anak selain memberikan hiburan sesungguhnya menyimpan sebuah keunikan, kesenian dan manfaat yang lebih besar seperti kerja sama tim, olahraga. Permainan tradisional anak dapat mengembangkan kreatifitas, ketangkasan, jiwa kepemimpinan, kecerdasan, kemampuan bahasa, kognitif, fisik motorik, bahkan kemampuan sosial emosional. Selain itu dinyatakan bahwa perilaku sosial sangat penting untuk dikembangkan dalam pendidikan anak usia dini, di mana perilaku sosial menjadi pendukung dalam perjalanan hidup anak.

Kenyataan dilapangan banyak orang tua dan guru yang tidak mengetahui manfaat tersebut, bahkan orangtua dan guru sangat jarang masih mengingat bagaimana memainkannya dan jarang menceritakan permainan tradisional yang pernah dimainkan dulu pada anak-anaknya (Observasi TK. Aster Indah, 2019). Dahulu permainan tradisional Sumatera Barat seperti main kambingkambing, main galah, main cak mimin dan beberapa permainan tradisional anak lainnya adalah permainan populer bagi anak-anak, namun sekarang permainan tersebut sudah jarang dimainkan oleh anak-anak.

Hal ini diperkuat oleh penelitian Ode menyatakan bahwa globalisasi, sains, dan teknologi telah membuat sebagian besar orang tercabut dari akar budaya mereka yang mengakibatkan kepunahan budaya, sehingga Ode berpendapat bahwa, "the state should attribute culture as a national identity and should not share its development to the global market mechanism"'(Ode et al., 2018). Menurut Sibarani, negara harus mempertahankan budaya sebagai identitas nasional.

Berdasarkan pembahasan mengenai perilaku sosial di atas dapat disimpulkan bahwa Perilaku sosial merupakan suatu hubungan interaksi antara dua individu atau lebih dalam menjalani hubungan dengan orang lain yang dapat diterima oleh lingkungan sosial dalam 
hal tindakan dan ucapan. Perilaku sosial terjadi akibat adanya stimulus atau pengaruh dari lingkungan untuk bertingkah laku sesuai dengan harapan lingkungan di mana perilaku sosial anak dapat dilihat dalam bentuk kerjasama, dukungan sosial dan berbagi.

Ke 9 hasil penelitian relevan yang telah dipaparkan memiliki variabel yang sama dengan penelitian yang dilaksanakan yaitu berkaitan dengan perilaku sosial.

Adapun kebaruan dalam penelitian ini adalah berbeda dengan penelitian sebelumnya, penelitian ini menekankan secara spesifik terhadap perilaku sosial dengan menggunakan kegiatan permainan tradisional Sumatera Barat secara bersama sama dalam meningkatkan perilaku sosial anak.

Berdasarkan observasi awal peneliti di Taman Kanak-Kanak Aster Indah kelompok A yang berusia 4-5 tahun dengan jumlah anak 10 orang diantaranya 6 orang anak perempuan dan 4 orang anak laki-laki. Di TK Aster Indah ini kebanyakan anak yang belum mampu bekerjasama dengan temannya disaat bermain, anak sering berbicara keras (berteriak) kepada teman, guru atau orang tua, masih banyak anak yang tidak sabar dalam mengikuti peraturan permainan sehingga membuat anak jenuh dan bosan untuk mengikuti permainan hingga selesai, anak belum mampu berbagi mainan atau alat tulis lain dengan teman, masih banyaknya anak-anak mau menang sendiri, sebagian besar anak masih berkelompok sesuai dengan kesukaannya. Selain itu, proses pembelajaran lebih diutamakan pembelajaran calistung dan permainan tradisional masih jarang digunakan dalam mengembangkan aspek sosial anak (Observasi TK. Aster Indah, 2019).

Melihat kenyataan di lapangan dan dari hasil penelitian relevan tersebut, peneliti merasa perlu mengadakan penelitian dengan judul "Peningkatan Perilaku Sosial Anak Melalui Permainan Tradisional Sumatera Barat Kelompok A Taman Kanak-Kanak Aster Indah Korong Balai Satu". Peneliti berharap perilaku sosial anak dapat meningkat melalui kegiatan permainan tradisional Sumatera Barat sehingga berdampak positif terhadap aspek-aspek perkembangan lainnya.

\section{METODOLOGI}

Metode yang digunakan dalam penelitian ini adalah penelitian tindakan yang mengacu kepada model Kemiss dan Mc. Tagart. Adapun prosedur penelitian dalam penelitian ini adalah perencanaan, tindakan dan observasi, dan refleksi. Langkah ini dilakukan berulang sampai dicapai keberhasian atau hasil yang diinginkan. Setelah tahapan dari siklus satu selesai, kemudian dilanjutkan dengan perencanaan ulang, tindakan dan observasi, dan refleksi untuk siklus berikutnya.

Kriteria keberhasilan tindakan dalam penelitian ini mengacu pada criteria yang ditetapkan oleh Mills, yang menyatakan bahwa penelitian tindakan memiliki target persentase menjadi $71 \%$ setelah melakukan tindakan pada subjek penelitian. Artinya, penelitian ini dikatakan berhasil jika $71 \%$ dari jumlah anak di kelas sudah mencapai standar yang telah ditetapkan oleh kolaborator yaitu $75 \%$ dengan mempertimbangkan situasi dan kondisi sekolah.

Teknik pengumpulan data menggunakan observasi, wawancara, dokumentasi dan catatan lapangan. Teknik analisis data yang digunakan adalah analisa data kualitatif, analisa kuantitatif dan penafsiran data. Aktivitas dalam analisis data yaitu data reduction, data display dan conclusing drawing/verification.

Pengujian keabsahan data pada penelitian ini menggunakan: 1) teknik Triangulasi. Data yang diperoleh dengan wawancara, lalu dicek dengan observasi dan dokmentasi. 2) Kredibilitas (credibility) dimana hasil penelitian ini dapat dipercaya oleh partisipan, 3) Transferabilitas (transferability) yang merujuk pada kekuatan hasil penelitian untuk ditranfer pada konteks yang lain. 4) Komfirmabilitas (comfirmability) menunjukkan bahwa data yang diperoleh adalah netral atau objektif, menggambarkan keadaan sebenarnya.

\section{HASIL DAN PEMBAHASAN}

Temuan-temuan dalam penelitian, perilaku sosial melalui permainan tradisional Sumatera Barat. Setelah dilakukan proses tindakan dan pengamatan dilaksanakan dalam 
siklus 1, maka skor perilaku sosial dipaparkan sebagai berikut:

Tabel 4.1 Data skor perilaku sosial anak pada siklus 1

\begin{tabular}{cccrc}
\hline No & Responden & Skor & $\begin{array}{c}\text { Siklus 1 } \\
\text { katego } \\
\text { ri }\end{array}$ \\
\hline 1 & AIS & 63 & $62.50 \%$ & $\mathrm{MB}$ \\
2 & RAS & 60 & $59.67 \%$ & $\mathrm{MB}$ \\
3 & AZI & 61 & $61 \%$ & $\mathrm{MB}$ \\
4 & NAY & 77 & $76.83 \%$ & $\mathrm{BSH}$ \\
5 & AIN & 75 & $75 \%$ & $\mathrm{BSH}$ \\
6 & RAI & 58 & $57.83 \%$ & $\mathrm{MB}$ \\
7 & SYA & 62 & $62.33 \%$ & $\mathrm{MB}$ \\
8 & ZAK & 62 & $61.67 \%$ & $\mathrm{MB}$ \\
9 & ZIV & 57 & $56.67 \%$ & $\mathrm{MB}$ \\
10 & RAT & 77 & $76.67 \%$ & $\mathrm{BSH}$ \\
& Rata-rata & 65 & $65.02 \%$ & $\mathrm{BSH}$ \\
\hline
\end{tabular}

Berdasarkan pengamatan observer, terlihat baik guru dan peneliti masih sering memberikan intervensi dalam jalannya permainan, masih adanya anak tidak mau ikut berpatisipasi dalam kegiatan bermain, masih ada anak mau menang sendiri dan ada beberapa anak yang kurang memiliki ketertarikan dalam kegiatan permainan tradisional sumatera barat. Hal ini dikarenakan masih kurangnya tantangan dan media pembelajaran untuk menarik perhatian anakanak agar lebih semangat dalam permainan.

Selain itu peneliti juga kurang memberikan pujian dan memotivasi anak agar lebih aktif selama proses pembelajaran berlangsung. Hal ini dikuatirkan bahwa potensi yang dimiliki anak tidak berkembang secara optimal dan berdampak pada hasil evaluasi yang hasil target belum mencapai peningkatan sesuai TCP 75\%. Oleh sebab itu perlu dilakukan tindakan selanjutnya pada siklus berikutnya.

Setelah proses tindakan dan pengamatan dilaksanakan dalam siklus II, maka skor perilaku sosial dipaparkan sebagai berikut:
Tabel 4.2 Data skor perilaku sosial anak pada siklus II

\begin{tabular}{cccrc}
\hline No & Responden & Skor & $\begin{array}{c}\text { Siklus II } \\
\%\end{array}$ & $\begin{array}{c}\text { katego } \\
\text { ri }\end{array}$ \\
\hline 1 & AIS & 85 & $85.33 \%$ & BSB \\
2 & RAS & 83 & $82.67 \%$ & BSB \\
3 & AZI & 84 & $83.5 \%$ & BSB \\
4 & NAY & 88 & $87.83 \%$ & BSB \\
5 & AIN & 84 & $84.33 \%$ & BSB \\
6 & RAI & 81 & $81.67 \%$ & BSH \\
7 & SYA & 85 & $84.83 \%$ & BSB \\
8 & ZAK & 83 & $82.50 \%$ & BSB \\
9 & ZIV & 81 & $81.67 \%$ & BSB \\
10 & RAT & 88 & $88.17 \%$ & BSB \\
& Rata-rata & 84 & $84.25 \%$ & BSB \\
\hline
\end{tabular}

Merujuk pada kesepakatan antara peneliti dan kolaborator dimana persentase rata-rata kriteria keberhasilan yang ditetapkan sebesar $75 \%$, maka penelitian yang dilakukan di kelompok A TK Aster Indah dinyatakan berhasil karena anak telah mengalami peningkatan perolehan skor minimal $75 \%$. Peningkatan keberhasilan penelitian di awal pra-tindakan dilakukan untuk menentuan persentase perilaku sosial anak sebesar $48.70 \%$, meningkat menjadi $65.02 \%$ pada siklus I, dan meningkat menjadi $84.25 \%$ setelah siklus kedua. Berikut akan disajikan grafik tingkat capaian perkembangan perilaku sosial anak pada pra siklus, siklus I, dan siklus II.

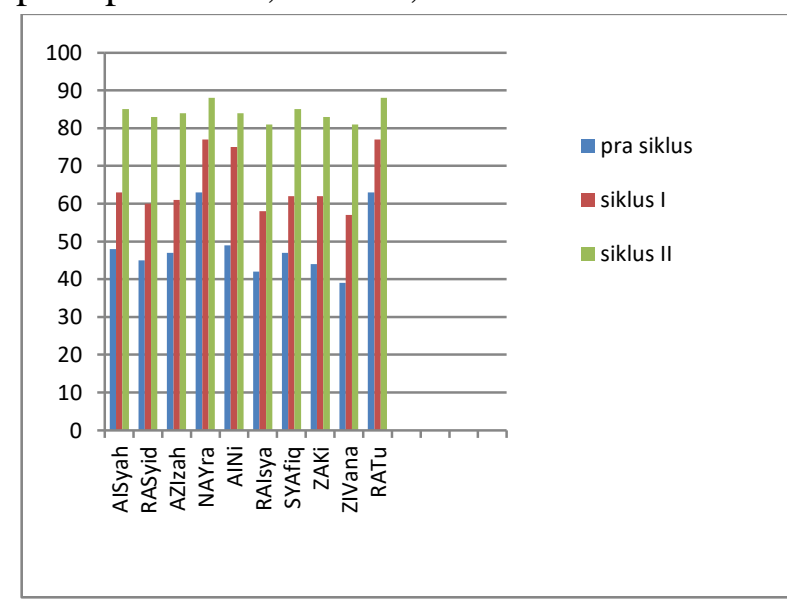

Garafik 1 capaian perkembangan perilaku sosial anak pada pra siklus, siklus I, dan siklus II.

Hasil penelitian ini memberikan gambaran secara teoritis tentang peningkatan perilaku sosial melalui kegiatan permainan tradisional Sumatera Barat. Perilaku sosial dapat ditingkatkan melalui kegiatan bermain. Melalui kegiatan bermain, mereka mendapat pengetahuan dan pengalaman. Pada saat 
bermain anak-anak juga belajar melalui interaksi dan pengalaman-pengalaman nyata dalam kehidupan sehari-hari. Melalui pembelajaran nyata dan eksplorasi terhadap lingkungan, anak-anak belajar membangun pengetahuannya.

Hal itu sejalan dengan pernyataan Büşra Ergin, Esra Ergin dalam jurnalnya "The Predictive Power of Preschool Children's Social Behaviors on Their Play Skills" Hasil menujukkan bahwa ada korelasi positif yang signifikan antara perilaku sosial positif anakanak dan keterampilan bermain (Ergin \& Ergin, 2017). Berdasarkan hasil penelitian tersebut menggambarkan bahwa dengan keterampilan bermain dapat menstimulasi perkembangan perilaku sosial anak.

Pendapat ini juga didukung oleh pendapat Khasanah, et..al. dalam jurnalnya permainan tradisional sebagai media stimulasi aspek perkembangan anak usia dini yang hasilnya menunjukkan bahwa permainan tradisional tersebut merupakan sarana dalam mengembangkan aspek perkembangan dasar anak (fisik-motorik, kognitif, sosial-emosional dan bahasa (Khasanah et al., 2011). Berdasarkan hasil penelitian menggambarkan bahwa kultur permainan tradisional mempunyai banyak manfaat bagi perkembangan aspek anak.

Sejalan dengan pendapat Lestariningrum melalui permainan tradisional dapat memberikan salah satu kegiatan pembelajaran menjadi pilihan yang efektif yang dapat dilakukan dalam meningkatkan kecerdasan anak (Lestariningrum \& Crie, 2017). Permainan tradisional adalah suatu produk bentuk permainan anak-anak yang memiliki ciri kedaerahan asli serta sesuai dengan aspek budaya dalam kehidupan masyarakat yang dapat digunakan sebagai pembelajaran. Permainan rakyat tersebut bukan hanya bertujuan untuk menghibur dan bersenangsenang namun juga untuk menjaga hubungan sosial (Chasanah, 2015).

Temuan dalam proses tindakan saat melakukan kegiatan permainan tradisional Sumatera Barat dalam meningkatkan perilaku sosial, diantaranya:
Pertama, melalui kegiatan permainan tradisional Sumatera Barat, anak-anak dapat belajar bekerja sama dengan orang lain. Hal ini terlihat ketika anak-anak dapat memberikan bantuan pada teman ketika ada teman yang belum menyelesaikan tugasnya. Anak juga dapat berperan aktif dalam kegiatan permainan tradisional Sumatera Barat secara berkelompok dan Anak juga dapat bermain dengan teman. Terlihat sekali bahwa permainan tradisional Sumatera Barat dapat melatih anak untuk dapat bekerja sama dengan orang lain. Hal ini sejalan dengan penelitian Minartin bahwa metode bekerja kelompok dapat meningkatkan kerjasama anak, dimana saat kegiatan pembelajaran anak dibagi dalam kelompokkelompok, hal ini bertujuan agar anak melatih dirinya untuk bekerja sama dengan yang lain, setelah pembagian kelompok kegiatan pembelajaran dilaksanakan guru menggunakan media melalui gambar dalam proses pembelajaran (Minartin, 2013).

Kedua, pada saat anak-anak melakukan kegiatan permainan tradisional Sumatera Barat, anak-anak dapat melakukan dukungan sosial dengan orang lain. Hal ini terlihat ketika anakanak dapat menghargai hasil karya teman. Anak dapat mendengarkan teman dan guru ketika berbicara. Anak dapat meminta maaf kepada teman ketika bersalah dan anak mau bergantian saat berbicara. Hal ini sejalan dengan penelitian Tatjana Kovačević and Siniša Opić bahwasanya permainan tradisional memberikan kontribusi terhadap kualitas hubungan dan frekuensi siswa (Kovačević \& Opić, 2014). Dengan kata lain, permainan tradisional Sumatera Barat dapat membantu perkembangan seluruh aspek anak yang berkaitan dengan interaksi sosial dan dukungan sosial anak pada sesama temannya.

Temuan ketiga yaitu dengan permainan tradisional Sumatera Barat, anak-anak dapat melakukan berbagi dengan orang lain. Hal ini terlihat ketika anak-anak dapat meminjamkan mainan dengan orang lain. Anak dapat berbagi makanan/minuman dengan temannya dan Anak-anak juga mau menggunakan mainan secara bergiliran. Hal ini sejalan dengan penelitian Hapidin bahwa permainan tradisional edukatif akan membantu anak 
mengembangkan berbagai aspek perkembangan secara holistik dan terintegrasi serta terbangunnya karakter positif (Hapidin, 2016). Dengan kata lain bahwa permainan tradisional dapat menstimulasi seluruh aspek bahkan termasuk karakter, perilaku sosial maupun saling berbagi.

\section{KESIMPULAN}

Hasil penelitian ini memberikan implikasi terutama berkaitan dengan perencanaan dan pengembangan pembelajaran di TK. Penelitian ini mengungkapkan bahwa permainan tradisional Sumatera Barat dapat digunakan sebagai pembelajaran untuk meningkatkan perilaku sosial. Hasil penelitian tentang peningkatan perilaku sosial melalui permainan tradisional Sumatera Barat dapat ditarik kesimpulan, yaitu kegiatan permainan tradisional Sumatera Barat dapat meningkatkan perilaku sosial anak TK.

\section{UCAPAN TERIMA KASIH}

Dengan menyelesaikannya karya ilmiah ini, penulis mengucapkan terimakasih yang sedalam-dalamnya kepada: Allah S.W.T atas limpahan karunia dan hidayahnya sehingga penulis dapat melaksanakan penelitian dan menyelesaikan karya ilmiah, Dosen pembimbing saya atas arahan dan koreksinya selama penyusunan dan penulisan karya ilmiah, kedua orang tua saya yang telah membantu dan mendukung saya dalam mengerjakan karya ilmiah ini, dan siswa siswi TK. Aster Indah Korong Balai Satu atas kerjasamanya selama penulis melakukan penelitian.

\section{DAFTAR PUSTAKA}

Chasanah. (2015). Pengembangan permainan tradisional gotri untuk pembelajaran fisik motorik kasar anak. Jurnal PG-PAUD Trunojoyo, Volume 2, 76-149.

Ergin, B., \& Ergin, E. (2017). The predictive power of preschool children's social behaviors on their play skills, 5(9), 140145. https://doi.org/10.11114/jets.v5i9.2601

Findlay, L. C., Girardi, A., \& Coplan, R. J. (2006). Links between empathy, social behavior, and social understanding in early childhood. Early Childhood
Research Quarterly, 21, 347-359. https://doi.org/10.1016/j.ecresq.2006.07.0 09

Hapidin, Y. (2016). Pengembangan model permainan tradisional dalam membangun karakter anak usia dini. Jurnal Pendidikan Usia Dini, Volume 10, 201-212. https://doi.org/https://doi.org/10.21009/JP UD. 102

Hurlock, E. B. (1980). Psikologi perkembangan suatu pendekatan sepanjang rentang kehidupan (5th ed.). jakarta: Erlangga.

Karachle, N., Dania, A., \& Venetsanou, F. (2012). Effects of a recreational gymnastics program on the motor proficiency of young children. Science of Gymnastics Journal, 9(1), 17-25.

Khasanah, I., Prasetyo, A., \& Rakhmawati, E. (2011). Permainan traditional sebagai media stimulasi aspek perkembangan anak usia dini. Jurnal Penelitian Paudia, Volume 1 No. 1 2011, 1(1), 91-105.

Kovačević, T., \& Opić, S. (2014). Contribution of traditional games to the quality of students 'relations and frequency of students, socialization in primary education. Croatian Journal of Education, 16(1), 95-112.

Lestariningrum, A., \& Crie, M. (2017). Analisi Pengembangan Kecerdasan Logis Matematis Anak Usia 5-6 Tahun Menggunakan Permainan Tradisional. Jurnal Pendidikan Usia Dini, Volume 11, 215-225.

https://doi.org/https://doi.org/10.21009/JP UD. 112.02

Mafra, H. (2015). Development of learning and social skills in children with learning disabilities: an educational intervention program. Procedia - Social and Behavioral Sciences, 209(July), 221-228. https://doi.org/10.1016/j.sbspro.2015.11.2 20

Mensah, F. K., Ph, D., Bayer, J. K., Ph, D., Clinical, M. P., Wake, M., ... D, M. (2013). Early puberty and childhood social and behavioral adjustment. Journal of Adolescent Health, 53(1), 118-124. https://doi.org/10.1016/j.jadohealth.2012. 12.018

Minartin. (2013). Meningkatkan perilaku sosial anak melalui metode kerja kelompok pada kelompok A di tk aisyiyah bustanul athfal toboli. Jurnal Kreatif Tadulako Online Vol . 1 No . 3 ISSN 2354-614X, 1(3), 157171. 
Observasi TK. Aster Indah. (2019). Observasi awal pada tk. aster indah (lampiran). Padang Pariaman.

Ode, L., Basri, A., Momo, A. H., Marhadi, A., Rahman, A., Ode, L., \& Jers, T. (2018). The unsustainability of kalego traditional game among muna community of watopute district. Asian Social Science, $14(2)$, https://doi.org/10.5539/ass.v14n2p12

Omeroglu, E. (2015). Determination and interpretation of the norm values of preschool social skills rating scale teacher form. Education Sciences Theory \& Practice, 15(4), 981-996. https://doi.org/10.12738/estp.2015.4.2514

Pekdoğan, S. (2016). Investigation of the effect of story based social skills training program on the social skill development of 5-6 year-old children. Education and Science, 41(183), 305-318. https://doi.org/10.15390/EB.2016.4618

Rachmana, Y. S. (2013). Perilaku sosial pada anak usia dini yang mendapat pembelajaran bilingual. Character, 1 Nomor 03, 1-13.

Ren, Y., \& Wyver, S. (2016). Social competence, cultural orientations and gender differences : a study of mandarin english bilingual preschoolers, 9760(April).

https://doi.org/10.1080/09669760.2016.11 38282

Richard Claproth, P. D. (2012). Dahsyatnya bahaya aktivasi otak tengah. jakarta: Grasindo.

Solberg, I. (2016). Land art in preschools. an art practice. International Journal of Education \& the Arts, Volume 17(ISSN: 1529-8094). Retrieved from http://www.ijea.org/

Susanto, A. (2015). Bimbingan dan konseling di taman kanak-kanak. jakarta: PrenadaMedia Group.

Takahashi, Y., Okada, K., Hoshino, T., \& Anme, T. (2015). Developmental trajectories of social skills during early childhood and links to parenting practices in a japanese sample. Plos One, 1-14. https://doi.org/10.1371/journal.pone.0135 357

Tri, A. F. L. (2016). Perilaku sosial anak usia dini di lingkungan lokalisasi guyangan. Jurnal Pendidikan Usia Dini, Volume 10, 121-134. https://doi.org/https://doi.org/10.21009/JP UD.101.07 Perilaku
Veiga, G., Neto, C., \& Rieffe, C. (2016). Preschoolers' free play - connections with emotional and social functioning, 8(1), 48-62. 